Case Report

\title{
Aplasia Cutis Congenita of the Scalp with a Familial Pattern
}

\author{
Waleed AlShehri, Sara AlFadil, Alhanouf AlOthri, Abdulaziz O. Alabdulkarim, \\ Shabeer A. Wani, and Sari M. Rabah
}

Department of Plastic \& Reconstructive Surgery, King Fahad Medical City, Riyadh 11525, Saudi Arabia

Correspondence should be addressed to Sara AlFadil; sara.alfadil@hotmail.com

Received 23 January 2016; Accepted 5 June 2016

Academic Editor: Yueh-Bih Tang

Copyright (C) 2016 Waleed AlShehri et al. This is an open access article distributed under the Creative Commons Attribution License, which permits unrestricted use, distribution, and reproduction in any medium, provided the original work is properly cited.

Aplasia Cutis Congenita (ACC) is a condition characterized by congenital absence of skin, usually on the scalp. ACC can occur as an isolated condition or in the presence of other congenital anomalies. Here we describe a case of a 16-day-old baby girl with an isolated ACC of the scalp. Her elder two siblings have been diagnosed with ACC with concomitant cardiac or limb anomalies. The patient was managed conservatively until the defect has formed scar tissue 6 months later.

\section{Introduction}

Cutis aplasia or Aplasia Cutis Congenita (ACC) is an uncommon and rare congenital abnormality involving variant layers of the skin, mostly as a solitary lesion involving the midline over the skull vertex and, less commonly, underlying periosteum and bone [1]. It may occur in other sites as well such as the chest, abdomen, or limbs [2,3]. Of lesions on the scalp, $20 \%$ involve the cranium, exposing the underlying dura membrane. ACC could also be found in other congenital anomalies; since it was first described in 1767 by Cordon, around 500 similar cases have been reported so far [4]. Frieden classified the different anomalies into 9 groups based on the number and the presence or absence of other anomalies (Table 1) [5]. The lesions in those cases are quite variable, ranging from only local absence of skin to a complete absence of epidermis, subcutaneous tissue, bone, or in some cases the dura [6-8]. The incidence of ACC is estimated as 1 per 10,000 live births [1]. This failure of formation is frequently more observed in females. The etiology remains unclear so far; however, both genetic and environmental causes have been implicated, including vascular blood supply, a sudden arrest of midline embryological development, and failure in neural tube closure, and syphilis has at one time contributed as the cause $[1,9]$. Rupture of amniotic membrane in an early time, forming amniotic bands, may also be from the cause [5]. A number of teratogenic drugs such as Methimazole, a Thiomidazole derivative used as an antithyroid agent, have shown to be involved [10-13]. There are similar cases, classified as being of an autosomal-dominant inheritance [14]. Establishing a diagnosis is usually based on the findings of the clinical examination, typically presenting as a hairless, smooth skin defect covered up by atrophic tissue or a darkcolored eschar. Superficial defects presenting as an ulcer are usually treated conservatively. Extensive or deep defects may require reconstruction of the scalp area or the use of bone transplants. However, hairless or scarcely haired scars mandate excision of the lesion and covering it with local flap from the scalp [9, 15-20].

\section{Case Report}

A 16-day-old newborn Female from Saudi Arabia presented to the clinic with a skin defect localized to the scalp since birth. The baby did not suffer from any ailments, and her medical history was unremarkable. Her mother, 32 years old, denied any history of illnesses during her pregnancy, infection, or drug intake taking including Nonsteroidal AntiInflammatory Drugs (NSAID) or Methimazole. She completed 38 weeks of gestation and delivered her baby via a normal vaginal delivery. The newborn did not sustain any birth injury and did not suffer from any other abnormalities or feeding difficulties. She did not require any intensive care and went home from hospital with her mother. Upon 
TABLE 1: Classification for ACC.

\begin{tabular}{|c|c|c|c|}
\hline & Group & Associated anomalies & Inheritance \\
\hline 1 & $\begin{array}{l}\text { Scalp ACC without multiple } \\
\text { anomalies }\end{array}$ & $\begin{array}{l}\text { Cleft lip and palate, tracheoesophageal fistula, patent ductus } \\
\text { arteriosus, omphalocele, mental retardation, polycystic kidneys }\end{array}$ & $\begin{array}{l}\text { Autosomal dominant } \\
\text { or sporadic }\end{array}$ \\
\hline 2 & $\begin{array}{l}\text { Scalp ACC with limb } \\
\text { abnormalities }\end{array}$ & $\begin{array}{l}\text { Limbs reduced, syndactyly, clubfoot, encephalocele, nail } \\
\text { dystrophy or absence, persistent cutis marmorata }\end{array}$ & Autosomal dominant \\
\hline 3 & $\begin{array}{l}\text { Scalp ACC with skin/organoid } \\
\text { nevi }\end{array}$ & $\begin{array}{l}\text { Epidermal nevi, organoid nevi, corneal opacities, scleral } \\
\text { dermoids, eyelid colobomas, mental retardation, seizures }\end{array}$ & Sporadic \\
\hline 4 & $\begin{array}{l}\text { ACC overlying embryologic } \\
\text { malformations }\end{array}$ & $\begin{array}{l}\text { Meningomyelocele, spinal dysraphia, cranial stenosis, } \\
\text { leptomeningeal angiomatosis, gastroschisis, congenital midline } \\
\text { porencephaly, ectopia of ear, omphalocele }\end{array}$ & $\begin{array}{l}\text { Depends upon } \\
\text { underlying condition }\end{array}$ \\
\hline 5 & $\begin{array}{l}\text { ACC with fetus papyraceus or } \\
\text { placental infarcts }\end{array}$ & $\begin{array}{l}\text { Single umbilical artery spastic developmental delay, spastic } \\
\text { paralysis, clubbed hands and feet, amniotic bands }\end{array}$ & Sporadic \\
\hline 6 & $\begin{array}{l}\text { ACC associated with } \\
\text { epidermolysis bullosa }\end{array}$ & $\begin{array}{l}\text { Blistering of skin and/or mucous membranes, deformed nails, } \\
\text { pyloric or duodenal atresia, abnormal ears and nose, ureteral } \\
\text { stenosis, renal anomalies, amniotic bands }\end{array}$ & $\begin{array}{l}\text { Depends upon type of } \\
\text { epidermolysis bullosa }\end{array}$ \\
\hline 7 & $\begin{array}{l}\text { ACC localized to extremities } \\
\text { without blistering }\end{array}$ & None & $\begin{array}{l}\text { Autosomal dominant } \\
\text { or recessive }\end{array}$ \\
\hline 8 & ACC caused by teratogens & $\begin{array}{l}\text { Imperforate anus (methimazole), other signs of intrauterine } \\
\text { infection with varicella or herpes simplex }\end{array}$ & Not inherited \\
\hline 9 & $\begin{array}{l}\text { ACC associated with congenital } \\
\text { syndromes }\end{array}$ & $\begin{array}{l}\text { Trisomy } 13,4 \text {-syndrome, ectodermal dysplasia, focal dermal } \\
\text { hypoplasia, amniotic band disruption complex, XY gonadal } \\
\text { dysgenesis, Johanson-Blizzard syndrome }\end{array}$ & $\begin{array}{l}\text { Depends upon } \\
\text { syndrome }\end{array}$ \\
\hline
\end{tabular}

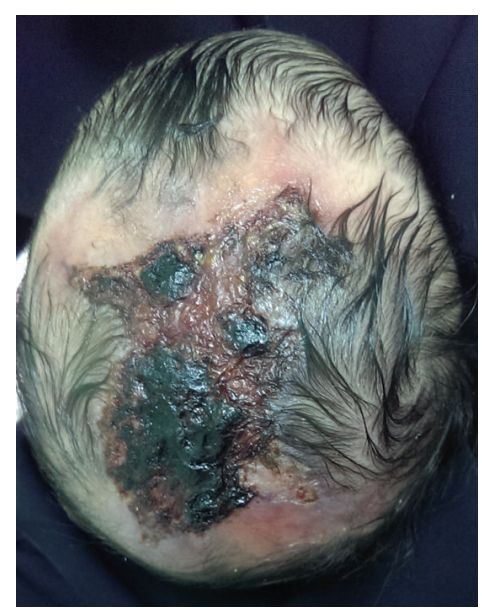

FIGURE 1: The newborn presented with skin defect of the scalp with an overlying crust.

local examination, the defect was solitary, localized with an irregular shape and approximately $6 \times 6 \mathrm{~cm}$ in size (Figure 1). The lesion involved the epidermis and the upper dermis only. Neurosurgical team was involved in the care of this patient. A CT scan of the head was performed, and no deep tissue involvement was noted. Reconstruction solutions were offered to the parents but they insisted on nonsurgical intervention. Therefore, the patient was treated with noninvasive debridement of the lesion and local therapy, including gentle water cleansing and the application of topical antibiotic ointment. Six months later, the patient has returned for a follow-up. Scar tissue has formed over the defect (Figure 2). Family history revealed that none of her parents had the

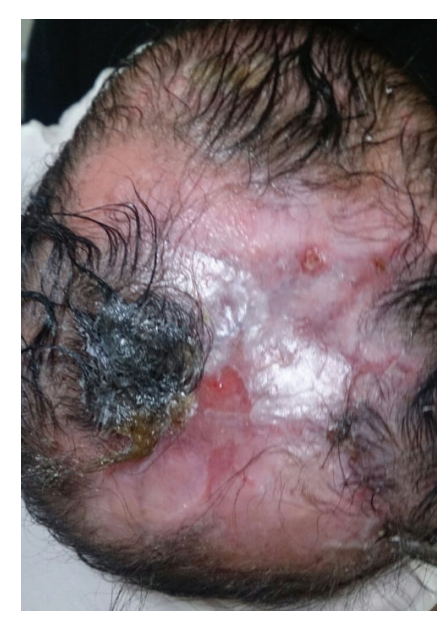

FIgURE 2: Six-month follow-up shows scar formation over the affected area.

same condition; however, two of her sisters did and were diagnosed with cutis aplasia. The elder one is currently 4 years of age, with right unilateral terminal reduction of the first and second toes (Figure 3). The other sister was born prematurely and died shortly after birth due to cardiac anomalies.

\section{Discussion}

ACC occurs as a solitary defect; it can happen alone or in the presence of syndromic congenital anomalies. The involvement of the scalp area may lead to the understanding of the etiology. Upon our review to the literature available, cases were often characterized by an entire absence of skin 


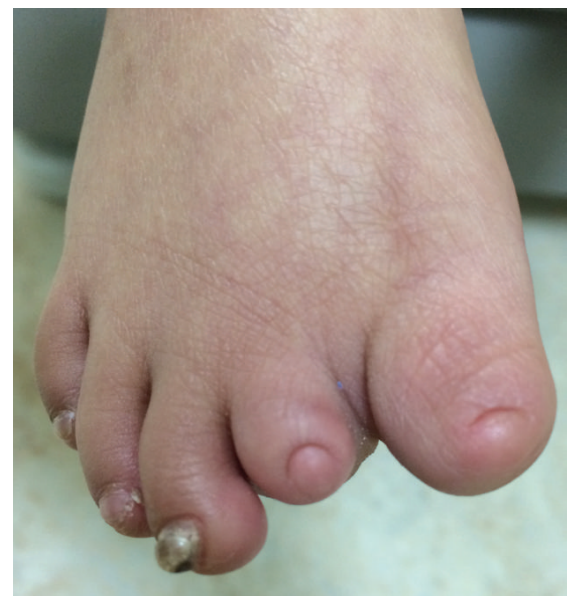

FIGURE 3: Unilateral terminal reduction of the right first and second toe.

and subcutaneous tissues. Histologically, we found that most of the lacking tissues belonged to epithelial ectoderm. The condition could be associated with chromosomal defects [21]. Some researches show the association with gestational conditions such as an intrauterine vascular ischemia, amniotic adherences, and viral infections [22, 23]. A rise of alpha-fetoprotein levels and a distinct amniotic fluid acetylcholinesterase band were found in recent article as markers for ACC [24]. Also, a number of drugs have been linked to ACC. For example, the use of cocaine during pregnancy can lead to vasoconstriction of the placenta or disruption of the fetus vascularity, causing the cranial defects and anomalies of the central nervous system (CNS) [25]. Methimazole, a drug used for the treatment of hyperthyroidism, may show some skin affection. Benzodiazepines use is also linked with ACC as described by Martínez-Lage et al. [7]. Surgical treatment requires careful preoperative planning [26]. Minimal superficial lesions are treated conservatively to heal gradually by reepithelialization and result with a hypertrophic or atrophic scar. Tissue expander insertion may be necessary in extensive lesions reaching the scalp, whereas the one deep enough to reach the brain, bone, and meningeal transplants may be indicated $[9,15,20,27]$. Deep defects overlying the sagittal sinus are indicators for urgent surgical intervention to prevent potentially lethal infections or hemorrhage [2830]. Grafting [31] and temporary use of biological dressings [32] and silver sulfadiazine dressings while waiting for the processes of skin and bony ingrowth [3] have been published with variable degree of success.

\section{Conclusion}

Aplasia Cutis Congenita is a rare congenital disorder characterized by absence of skin, most frequently overlying the scalp. ACC can be associated with many anomalies. We report a case of a newborn with isolated scalp ACC, which was treated conservatively. Although neither of the parents had ACC, two of the patient's siblings have ACC of the scalp with concomitant cardiac or limb anomalies.

\section{Competing Interests}

The authors declare no competing interests.

\section{References}

[1] M. Bajpai and K. Pal, "Aplasia cutis cerebri with partial acrania-total reconstruction in a severe case and review of the literature," Journal of Pediatric Surgery, vol. 38, no. 2, article e4, 2003.

[2] J. K. O’Neill, M. Carter, and R. P. Warr, “Aplasia cutis congenita. A case of scalp defect repair using two opposing bipedicled local flaps," Journal of Plastic, Reconstructive and Aesthetic Surgery, vol. 63, no. 3, pp. e242-e244, 2010.

[3] K. Blunt, V. Quan, D. Carr, and B. A. Paes, "Aplasia cutis congenita: a clinical review and associated defects," Neonatal Network, vol. 11, no. 7, pp. 17-27, 1992.

[4] M. Cordon, "Extrait d'une lettre au sujet de trois enfants de la meme mere nex avec partie des extremites denuee de peau," Journal de Médecine, Chirurgie, Pharmacie, vol. 26, pp. 556-557, 1767.

[5] I. J. Frieden, "Aplasia cutis congenita: a clinical review and proposal for classification," Journal of the American Academy of Dermatology, vol. 14, no. 4, pp. 646-660, 1986.

[6] L. P. Lassman and D. G. Sims, "Congenital midline scalp and skull defect," Archives of Disease in Childhood, vol. 50, no. 12, pp. 958-960, 1975.

[7] J. F. Martínez-Lage, M. J. Almagro, F. L. Hernández, and M. Poza, "Aplasia cutis congenita of the scalp," Child's Nervous System, vol. 18, pp. 634-637, 2002.

[8] H. Aloulou, W. Chaari, S. Khanfir et al., "Aplasia cutis congenita of the scalp (5 observations)," Archives de Pediatrie, vol. 15, no. 4, pp. 382-387, 2008.

[9] L. C. Argenta and R. O. Dingman, "Total reconstruction of aplasia cutis congenita involving scalp, skull, and dura," Plastic and Reconstructive Surgery, vol. 77, no. 4, pp. 650-653, 1986.

[10] M. Inoue, N. Arata, G. Koren et al., "Hyperthyroidismduring pregnancy," Canadian Family Physician, vol. 55, pp. 701-703, 2009.

[11] H. Iwayama, H. Hosono, H. Yamamoto, M. Oshiro, and N. Ueda, "Aplasia cutis congenita with skull defect in a monozygotic twin after exposure to methimazole in utero," Birth Defects Research Part A: Clinical and Molecular Teratology, vol. 79, no. 10, pp. 680-684, 2007.

[12] M. Abe, T. Syuto, Y. Yokoyama, and O. Ishikawa, "Aplasia cutis congenita after methimazole exposure in utero successfully treated with basic fibroblast growth factor," International Journal of Dermatology, vol. 49, no. 3, pp. 334-335, 2010.

[13] S. K. Baid and D. P. Merke, "Aplasia cutis congenita following in utero methimazole exposure," Journal of Pediatric Endocrinology and Metabolism, vol. 20, no. 5, pp. 585-586, 2007.

[14] M. R. Chitnis, R. Carachi, and P. Galea, "Familial aplasia cutis congenita," European Journal of Pediatric Surgery, vol. 6, no. 2, pp. 100-101, 1996.

[15] M. F. Attalla and A. M. El-Sayed, "Scalp aplasia cutis congenita: closure by the L-shaped flap," Child's Nervous System, vol. 8, no. 5, pp. 287-288, 1992.

[16] G. Borgnolo, F. Longo, G. Olivo, and G. Guidobaldi, "Aplasia cutis congenita: report of 4 additional cases and review of the literature," La Pediatria Medica e Chirurgica, vol. 16, no. 6, pp. 559-563, 1994 (Italian). 
[17] J. Kruk-Jeromin and E. Lewandowicz, "Congenital aplasia of scalp skin,” Przeglad Dermatologiczny, pp. 73908-73911, 1986 (Polish).

[18] D. A. Ross, S. W. S. Laurie, C. J. Coombs, and K. L. Mutimer, "Aplasia cutis congenita: failed conservative treatment," Plastic and Reconstructive Surgery, vol. 95, no. 1, pp. 124-129, 1995.

[19] L. M. Field, "Scalp flaps," The Journal of Dermatologic Surgery and Oncology, pp. 17190-17199, 1991.

[20] J. G. McCarthy, Ed., Plastic Surgery, Saunders, Philadelphia, Pa, USA, 1990.

[21] L. H. Honoré, F. J. Dill, and B. J. Poland, "Placental morphology in spontaneous human abortuses with normal and abnormal karyotypes," Teratology, vol. 14, no. 2, pp. 151-166, 1976.

[22] F. L. Mannino, K. L. Jones, and K. Benirschke, "Congenital skin defects and fetus papyraceus," The Journal of Pediatrics, vol. 91, no. 4, pp. 559-564, 1977.

[23] M. E. Evers, P. M. Steijlen, and B. C. Hamel, "Aplasia cutis congenital and associated disorders: an update," Clinical Genetics, vol. 47, pp. 295-301, 1995.

[24] Y. Dror, Z. Gelman-Kohan, Z. Hagai, A. Juster-Reicher, R. N.-B. Cohen, and B. Mogilner, "Aplasia cutis congenita, elevated alpha-fetoprotein, and a distinct amniotic fluid acetylcholinesterase electrophoretic band," American Journal of Perinatology, vol. 11, no. 2, pp. 149-152, 1994.

[25] C. B. Whitley and R. J. Gorlin, "Adams-oliver syndrome revisited," American Journal of Medical Genetics, vol. 40, no. 3, pp. 319-326, 1991.

[26] C. Goldberg, G. Fenelon, N. S. Blake, F. Dowling, and B. F. Regan, "Diastematomyelia: a critical review of the natural history and treatment," Spine, vol. 9, no. 4, pp. 367-372, 1984.

[27] D. Dyall-Smith, A. Ramsden, and S. Laurie, "Adams-Oliver syndrome: aplasia cutis congenita, terminal transverse limb defects and cutis marmorata telangiectatica congenita," Australasian Journal of Dermatology, vol. 35, no. 1, pp. 19-22, 1994.

[28] L. A. Peer and J. V. Duyn, "Congenital defect of the scalp: report of a case with fatal termination," Plastic and Reconstructive Surgery, vol. 3, no. 6, pp. 722-726, 1948.

[29] E. J. Kosnik and M. P. Sayers, "Congenital scalp defects: aplasia cutis congenita," Journal of Neurosurgery, vol. 42, no. 1, pp. 3236, 1975.

[30] L. A. Sargent, "Aplasia cutis congenita of the scalp," Journal of Pediatric Surgery, vol. 25, no. 12, pp. 1211-1213, 1990.

[31] M. F. B. Bailie, "Aplasia cutis congenita of neck and shoulder requiring a skin graft: a case report," British Journal of Plastic Surgery, vol. 36, no. 1, pp. 72-74, 1983.

[32] J. Lambert, P. Govaert, and J. M. Naeyaert, "What syndrome is this?” Pediatric Dermatology, vol. 14, no. 4, pp. 330-332, 1997. 


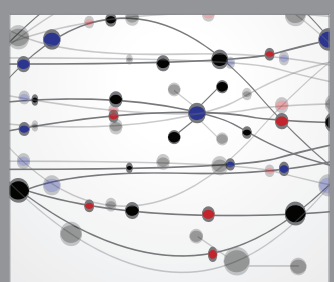

The Scientific World Journal
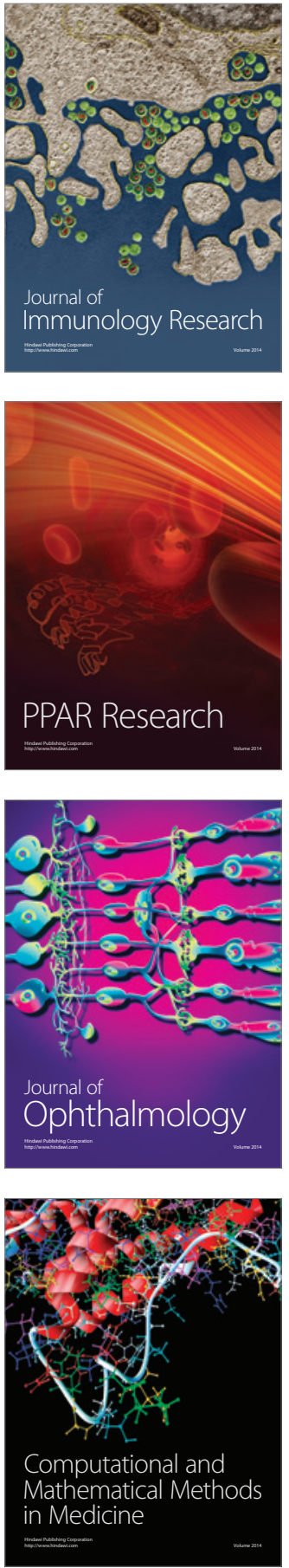

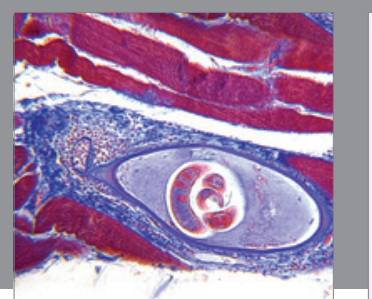

Gastroenterology Research and Practice

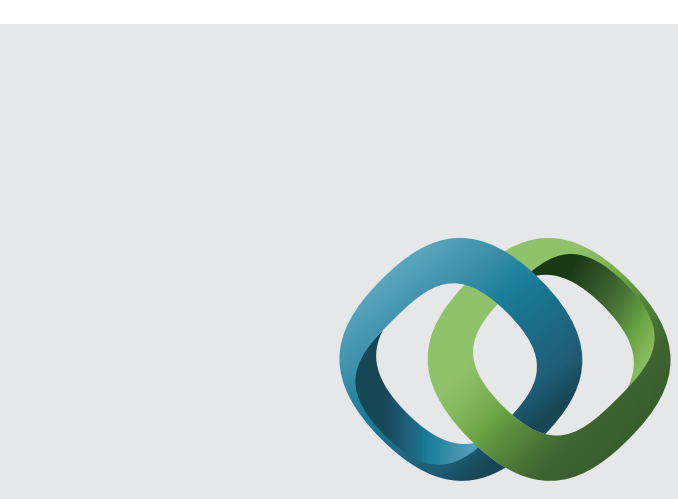

\section{Hindawi}

Submit your manuscripts at

http://www.hindawi.com
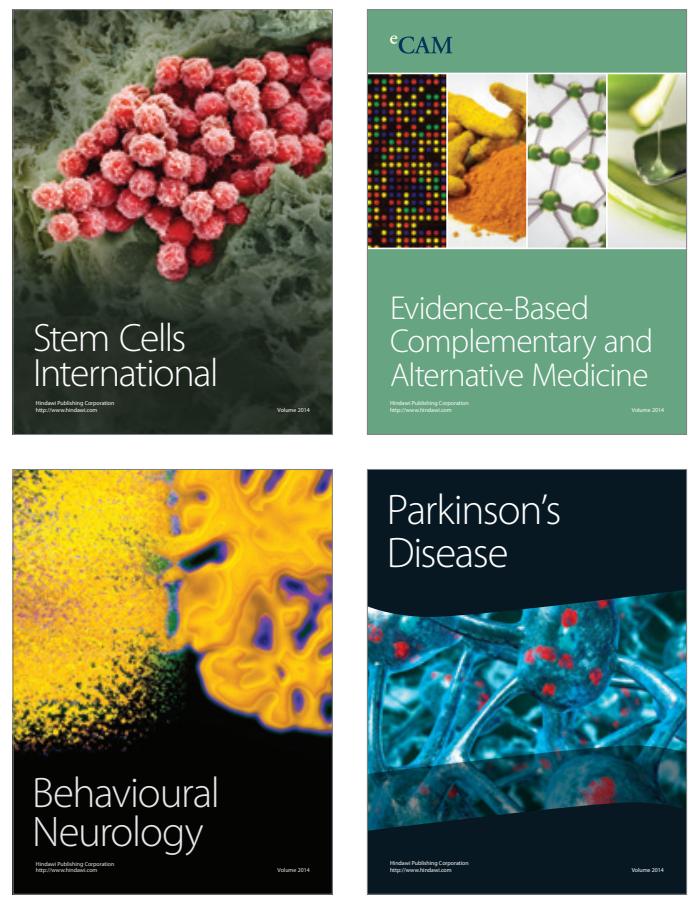
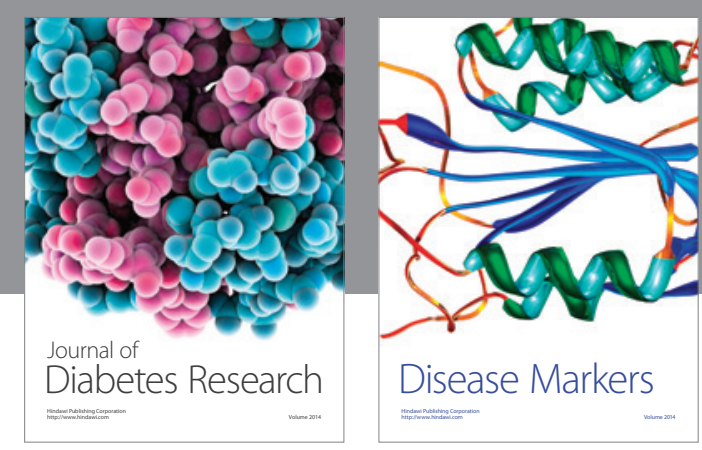

Disease Markers
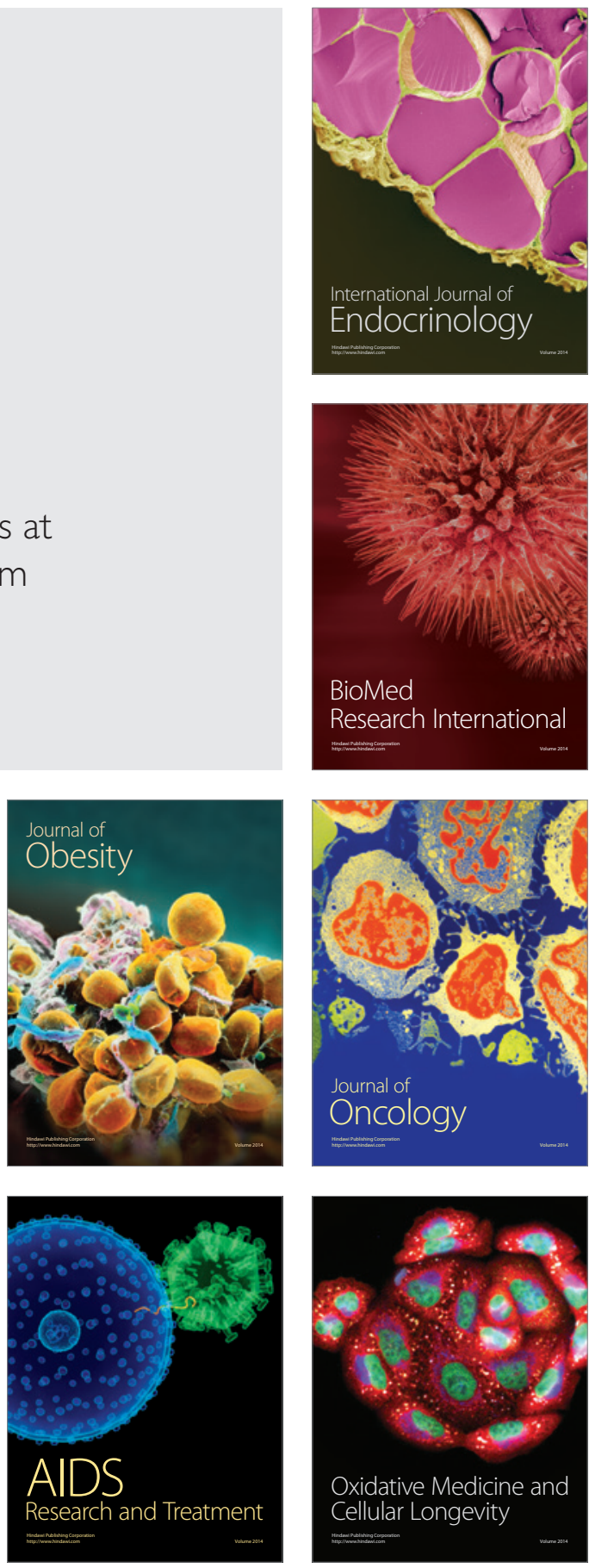